\section{DIARY}

British Dental Conference and Exhibition 2012

Date: 26-28 April 2012

Venue: Manchester Central

Convention Complex

www.bda.org/conference

The British Society for

Restorative Dentistry

Spring Scientific Meeting

Date: 4-5 May 2012

Venue: The University Arms Hotel,

Cambridge

Email: matthew.garrett@nhs.net

www.bsrd.org.uk

Current Concepts in Hard

Tissue Grafting for Accelerated Implant Reconstruction

Date: 18-19 May 2012

Venue: Spectrumsmiles, Jersey

Telephone: 01534743849

Email: info@spectrumsmiles.co.uk

www.courses4implants.com

Scottish Dental Show 2012

Date: 24-25 May 2012

Location: Hampden Park, Glasgow

www.scottishdentalmag.co.uk/show

11th Congress of the European

Academy of Paediatric Dentistry

A Crossroads of Knowledge,

Innovation and Expertise

Date: 24-27 May 2012

Venue: Convention Centre,

Strasbourg, France

www.eapd2011.eu

S4S Introduction to Occlusal

Splints for the GDP

Date: 25 May 2012

Location: London

Telephone: 01142500176

www.s4sdental.com

Dental Hypnosis 1:

Technical Foundations

Date: 13 June 2012

Location: Central London

Telephone: 02073851166

Email: info@ihmdp.org

Dental Hypnosis 2:

Applied Clinical Skills

Date: 14 June 2012

Location: Central London

Telephone: 02073851166

Email: info@ihmdp.org

\section{BDA BULLETIN}

- In January the BDA appealed to NHS Choices to consider the way that comments about dental practices posted on its site are moderated. The appeal has been made following feedback from a number of BDA members about the way that the site allows serious but unsubstantiated allegations to be made about practitioners anonymously and the often-slow process for moderating inappropriate comments.

- Dr John Milne has been re-elected as Chair of the BDA General Dental Practice Committee (GDPC). Dr Milne, who owns a practice in Wakefield, West
Yorkshire, first won the mandate to lead the UK's general dental practitioners in 2009.

- Dr Robert Kinloch has been re-elected as Chair of the BDA Scottish Dental Practice Committee (SDPC). Dr Kinloch is a general practitioner who practises at Alexandria, near Loch Lomond. He also chairs the BDA's Scottish Council and the UK Healthcare Policy Group and has served as SDPC Chair since January 2010

- A BDA report called Student futures warns that a cocktail of spiralling levels of debt for dental students, uncertainty about the financial support available to them, and concerns about changing career pathways, could conspire to dissuade capable young candidates from applying for careers in dentistry. Concerns over potential debts could be exacerbated by other changes that make the cost of studying a dental degree difficult to assess, says the report, including continued uncertainty about the student bursary system.

\title{
STUDY TARGETS 'COMMUNITY GANGS'
}

A study in the journal Microbiology says that stripping some mouth bacteria of their 'access keys' to other pathogenic oral bacteria could help prevent gum disease and tooth loss. ${ }^{1}$ The study suggests that this bacterial access key could be a drug target for people who are at high risk of developing gum diseases.

Oral bacteria of the species Treponema denticola frequently 'gang up' in communities with other pathogenic oral bacteria to produce destructive dental plaque. Researchers from the University of Bristol have discovered that a molecule on the surface of $T$. denticola called CTLP acts as the key pass that grants the bacterium access to the community, by allowing it to latch onto other oral bacteria. Once incorporated, CTLP in conjunction with other bacterial molecules can start to wreak havoc by inhibiting blood clotting (leading to continued bleeding of the gums) and causing tissue destruction.

'Devising new means to control these infections requires deeper understanding of the microbes involved, their interactions, and how they are able to become incorporated into dental plaque,' said Professor Howard Jenkinson, who led the study.

The study shows that CTLP could be a good target from which novel therapies could be developed and the research team is now working to find a compound that will inhibit CTLP.

1. Cogoni V, Morgan-Smith A, Fenno J C, Jenkinson H F, Dymock D. Treponema denticola chymotrypsin-like proteinase (CTLP) integrates spirochaetes within oral microbial communities. Microbiology 2012; Feb 7 [Epub ahead of print].

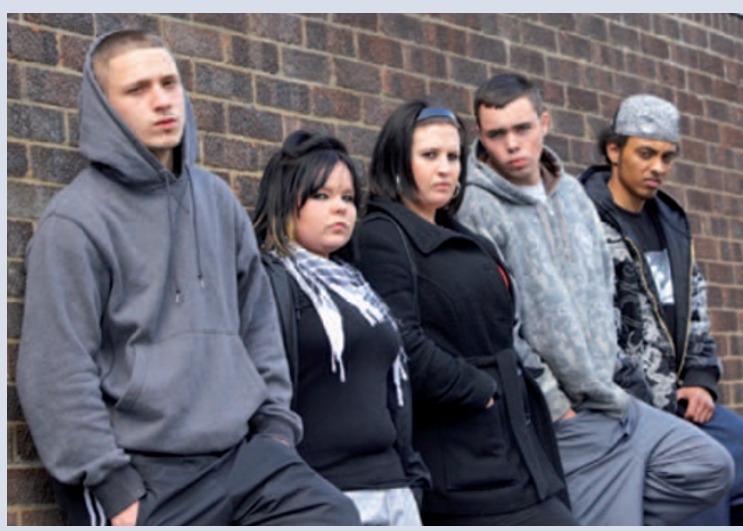

\section{VERY BRIEF}

\section{ADVICE TRAINING}

A free training module called 'Very Brief Advice' (VBA) has been published on the website of the NHS Centre for Smoking Cessation and Training (NCSCT). This free resource has been developed for healthcare

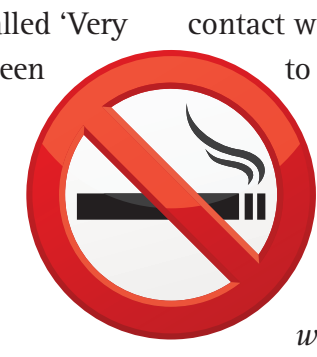

professionals to help increase the quality and frequency of VBA given to patients who smoke.

The training is relevant to anyone who comes into contact with smokers and takes under 30 minutes to complete. Upon successful completion a certificate is available to provide evidence of continuing professional development (CPD).

The free training module can be accessed at www.ncsct.co.uk/vba.

14 March 2012 is No Smoking Day. Visit www.nosmokingday.co.uk 